Submitted on May 2, 2020.

\title{
Ways to utilize by-products in the production of silica from rice husk
}

\author{
(C) Elena M. Gotlib, ${ }^{1 *}$ Thi Nha Phuong Ha, ${ }^{1,2+}$ and Nadezhda V. Shilnikova ${ }^{3}$ \\ ${ }^{1}$ Department of Technology of Synthetic Rubber. Institute of Polymer. ${ }^{3}$ Department of Industrial Safety. \\ Kazan National Research Technological University. Karl Marx St., 68. Kazan, 420015. Republic of Tatarstan. \\ Russia.Phone:+7 (843)231-42-14.E-mail: 1)egotlib@yandex.ru ; ${ }^{3)}$ snv-knitu@yandex.ru \\ ${ }^{2}$ Department of Chemistry. Viet Tri University of Industry. Tien Son St., 9. Viet Tri City. Phu Tho. Vietnam. \\ Phone:+7 (906)322-42-33.E-mail:phuonghtn@vui.edu.vn
}

\section{*Supervising author; ${ }^{+}$Corresponding author}

Keywords: rice husk, silicon dioxide, recycling of by-products, filler, epoxy materials, wear resistance, hardness, antifriction properties.

\section{Abstract}

The development of modern technologies for the use of rice husk $(\mathrm{RH})$ as a raw material for the production of silicon dioxide (DC) is relevant. However, in the process of obtaining DC from RH, as a rule, solutions of acids and alkalis use. This makes it important to search for rational ways to regenerate these liquids and utilize exhaust gas emissions into the atmosphere in order to solve the problems of environmental protection.

In the synthesis of DC based on RH, the following wastes are obtained: solid - carbon, liquid solutions of hydrochloric acid and sodium oxide, exhaust gases. For utilization of the latter, it is effective to use the absorption purification method, based on the absorption by liquid reagents of toxic gases and vapors from their mixtures with air. The resulting sludge can be effectively used as a filler, in the manufacture of pavements (for example, asphalt).

The resulting acidic wastewater can be used to neutralize alkaline solutions. After neutralization, in addition to discharging into the environment, these wastes can be used as chemical fertilizers (since they contain sodium chloride).

Carbon can be used in the production of effective sorbents used, for example, to eliminate oil spills in environmental emergencies.

Silicon dioxide obtained from rice husk is an effective filler of epoxy polymers, increasing their hardness, wear resistance and improving antifriction characteristics. It provides acceleration of the curing process and the formation of more denser cross linked structure of filled materials. The nature of the modifying action of silicon dioxide does not depend on the temperature of burning rice husk, which affects only the magnitude of the effects achieved.

\section{References}

[1] V.I. Sergienko, L.A. Zemnukhova, A.G. Egorov. Renewable sources of chemical raw materials: integrated waste processing of rice and buckwheat. Russian chemical journal. 2004. No.3. P.117-124. (russian)

[2] S.V. Efremova. Physico-chemical fundamentals and technology for the thermal processing of rice husks: [monograph]. S.V. Efremova. Almaty: [b. and.]. 2011.149 p.

[3] P.I. Soroka. Physicochemical basis of the process of obtaining silicon dioxide from rice husk, P.I. Soroka and others. Bulletin nat. tech. University "KhPI". 2010. No.10. P.124-134. (russian)

[4] A.B. Rohani, Y. Rosiyah, N.G. Seng. Production of High Purity Amorphous Silica from Rice Husk. Procedia Chemistry. 2016. Vol.19. P.189-195.

[5] Duy Hung Nguyen, L.A. Zenitova, Quang Dien Le, and Do Tien Thinh Bui. Use of burn rice residues for production of nanosilica. Butlerov Communications. 2019. Vol.57. No.3. P.155-161. DOI: 10.37952/ROIjbc-01/19-57-3-155

[6] E.M. Gotlib, T.N.P. Ha. Obtaining synthetic wollastonite based on rice husk. Bulletin of the University of Technology. 2019. Vol.22. No.7. P.42-46. (russian)

[7] M. Sudhakar, S.P. Samantarai, S.K. Acharya. Tribological behavior of modified rice husk filled epoxy composite. International Journal of Scientific \& Engineering Research. 2012. Vol.3(6). P.1-5. 
WAYS TO UTILIZE BY-PRODUCTS IN THE PRODUCTION OF SILICA FROM RICE HUSK

[8] L.A. Zemnukhova, G.A. Fedorishcheva, A.G. Egorov, V.I. Sergienko. Study of the conditions for the preparation, composition, impurities and properties of amorphous silicon dioxide from rice production waste, Journal of Applied Chemistry. 2005. Vol.78. Iss.2. P.324-328. (russian)

[9] Nguyen Van Hung, Nguyen Ngoc Bich, Nguyen Huu Nghi, Tran Huu Bang, Dang Thi Thanh Le. Nguyễn Văn Hưng, Nguyễn Ngọc Bích, Nguyễn Hữu Nghị, Trần Hữu Bằng, Đặng Thị Thanh Lê. Preparation of porous $\mathrm{SiO}_{2}$ nanomaterials made from rice husk ash to absorb methylene blue in water. Journal of Chemistry. 2015. Vol.53(4). №8. P.491-496.

[10] U. Kalapathy, A. Proctor, J. Shultz. An improved method for production of silica from rice hull ash. Bioresource Technology. 2002. Vol.85. Iss.3. P.285-289.

[11] G.K. Zibert, A.D. Sedykh, Yu.A. Kashitsky, N.V. Mikhailov, V.M. Demin. Preparation and processing of hydrocarbon gases and condensate. Technology and equipment: A reference guide. Moscow: JSC Nedra-Business Center. 2001. 316p. (russian)

[12] I.A. Borodina. Technology and physicochemical properties of composite materials based on natural silicates and unsaturated polyester resins: abstract. Dissertation of the candidate tech. sciences. Tomsk. 2005. 18p. (russian)

[13] Ghosh, S. Bhattacherjee. A review study on precipitated silica and activated carbon from rice husk. Journal of Chemical Engineering and Process Technology. 2013. Vol.4. Iss.4. P.156-162.

[14] Srisuwan et al. "Physical Properties of Rice Husk Fiber/Natural Rubber Composites". Advanced Materials Research. 2012. Vol.410. P.90-93.

[15] V.I. Kolesnikov, Yu. F. Migal, N. A. Myasnikova. Antifriction composite polymer materials for friction units. Tomsk State University Journal. South scientific center. 2004. P.13-16. (russian)

[16] D. Angelova. Kinetics of oil and oil products adsorption by carbonized rice husks. Chemical Engineering Journal. 2011. Vol.172(1). P.306-31143. 